\title{
Partisipasi Masyarakat Dalam Penyelenggaraan Pemilihan Kepala Daerah
}

\author{
Muhamad Azhar \\ Fakultas Hukum, Universitas Diponegoro \\ J1.Prof.Soedarto, SH Tembalang Semarang \\ azharundip@gmail.com
}

\begin{abstract}
This paper aims to find out how the principles of participation in the election of regional heads in Indonesia. The conventional method is an approach that uses a conceptual approach that can be used to analyze synthetic. The results of the study indicate that the basic principles for conducting the election of regional heads must be conducted at the time of openness as a basic principle of community participation. It must also be based on the Principle of Legal Certainty, the orderly principle of the state organizer, the public interest principle. principle of transparency, proportionality principle, principle of professionalism, principles of accountability, principles of efficiency and principle of effectiveness.
\end{abstract}

Keywords: Community Participation, Election of Head of Region, Basis of Openness.

\begin{abstract}
Abstrak
Tulisan ini bertujuan untuk mengetahui bagaimanakah prinsip partisipasi masyarakat dalam penyelenggaraan pemilihan kepala daerah di Indonesia. Metode penulisan merupakan penulisan hukum yang menggunakan pendekatan conceptual approach yang dianalisis menggunakan analisis sintensis. Hasil analisis menunjukan bahwa prinsip dasar partisipasi masyarakat terhadap penyelenggaran pemilihan umum kepala daerah harus senantiasa berdasarkan pada asas keterbukaan sebagai prinsip pokok partisipasi masyarakat. Selain itu juga harus berdasarkan pada Asas Kepastian Hukum, Asas Tertib Penyelenggara Negara, Asas Kepentingan Umum. Asas Keterbukaan, Asas Proporsionalitas, Asas Profesionalitas, Asas Akuntabilitas, Asas Efisiensi dan Asas Efektivitas.
\end{abstract}

Kata Kunci: Partisipasi Masyarakat, Pemilihan Kepala Daerah, Asas Keterbukaan.

\section{A. Pendahuluan}

Peranan masyarakat dalam mewujudkan pemilihan umum yang bersih, penyelenggaraan pemerintahan daerah yang demokratis dan akuntabel sangatlah strategis. Sejak hadirnya otonomi daerah secara hakiki menjadikan semakin dekatnya partisipasi masyarakat dalam penyelesaian masalah-masalah di daerah lebih terfokus dan mandiri. Teramsuk didalamnya pemilihan kepala daerah. Partisipasi masyarakat dalam 
penyelenggaraan pemilihan kepala daerah secara lebih luas dapat dilkukan dengan cara pengawasan lebih intensif terhadap penyelenggaraan pemilihan umum di daerah.

Hal tersebut akan menjadi lebih kuat dan nyata apabila pemerintahan daerah berlangsung secara partisipatif, baik pada tataran proses maupun substansinya, dan akuntabel. Demokratis secara proses, jika mampu memberikan ruang / kesempatan bagi partisipasi masyarakat dalam semua pembuatan dan pelaksanaan kebijakan daerah. Demokratis secara substansial, jika kebijakan-kebijakan daerah mencerminkan aspirasi masyarakatnya. Akuntabel, jika pemerintah daerah mampu menjalankan prosedurprosedur yang telah ada dan dapat mempertanggungjawabkannya kepada publik dalam penyelenggaraan pemilihan kepala daerah daerah secara umum maupun pembuatan kebijakan daerah.

Proses demokrasi adalah dari, oleh dan untuk rakyat. Demokrasi menjadi berkualitas ketika adanya peran serta, andil, keterlibatan rakyat dalam partisipasi dan pengawalan aktif. Peran serta rakyat menjadi poros strategis untuk mendorong kualitas demokrasi dan pemilu yang substantif. Dalam hal ini, pengawasan yang bersifat formal (Bawaslu dan jajarannya) bersama-sama dengan pengawasan partisipatif (rakyat) menjadi satu kesatuan dalam rangka mendorong pengawasan bersifat integratif partisipatif menuju Pemilihan dan Pemilihan Umum yang langsung, umum, bebas, rahasia serta jujur dan adil.

Memasuki tahapan Pemilu, khusus Provinsi Jawa Tengah akan mengadakan proses demokrasi dalam rangka Pilgub 2018. Disisi lain, berbarengan dengan persiapan tahapan Pemilu yakni pemilihan presiden dan pemilihan legislatif. Oleh karena itu, dibutuhkan peran serta pengawasan yang bersifat integratif - partisipatif baik lembaga formal maupun non formal untuk dan demi mensukseskan proses demokrasi yang semakin lebih kualitas.

Sebagai contoh, Secara regulasi "hajatan" demokrasi baik Provinsi Jawa Tengah (Pilkada) dan Nasional (Pilpres dan Pileg) sudah diatur dalam UU No. 10 Tahun 2016 Tentang pemilihan Gubernur dan Wakil Gubernur, Bupati dan Wakil Bupati dan/atau Walikota dan Wakil Walikota dan UU No. 7 Tahun 2017 Tentang Pemilihan Umum. Bahwa di dalam regulasi tersebut diatur tentang pengawasan partisipatif yang berasal dari masyarakat.

Secara praktek dilapangan soal pemilu, sampai saat ini masih menjadi tantangan tersendiri. Antara idealita dengan realitas masih terjadi jarak, misalnya masih diketemukan pelanggaran-pelanggaran, baik administrasi, pidana pemilu, kode etik serta 
sengketa. Salah satu penyebabnya adalah kurangnya penerapan prisnip keterbukan dalam penyelenggaraan pemilihan umum, termasuk didalamnya pemilihan kepala daerah.

Untuk menjawab tantangan realitas tersebut, paling tidak dengan pendorongan secara maksimal bentuk-bentuk pengawasan partisipatif adalah bagian dari solusi dalam membuat keadaan pemilu semakin kualitas, harapannya demikian. Tantangan tersebut menjadi tanggung jawab seluruh komponen masyarakat secara luas. Panitia pengawas pemilu menyadari masih mempunyai keterbatasan-keterbatasan, meskipun dalam regulasi sudah diberi wewenang. Hal ini lah peluang partisipasi masyarakat sebagai upaya untuk meningkatkan kualitas pemilihan umum, khususnya pemilihan umum kepala daerah.

Pengawasan pemilu partisipasi yang melibatkan masyarakat secara luas senantiasa didorong terus - menerus. Berbekal untuk kepentingan bangsa dan negara maka panggilan jiwa masyarakat akan bergerak menjadi bagian aktif dan partisipatif menjadi pengawas. Menjadi pengawas partisipatif tidak mengenal SARA dan gender semua bisa ambil bagian untuk pengawasan, apakah kalangan agama, masyarakat, pers / media, kampus, gender, kota, desa, pinggiran, profesional, buruh / marginal semua dapat berperan serta menjadi pengawas partisipatif.

Berdasarkan uraian tersebut maka tulisan ini ingin menguraikan sedikit terkait dengan bagaiamanakah prinsip dasar partisipasi masyarakat terhadap penyelenggaran pemilihan umum kepala daerah. Pertanyaan ini tentu saja penting mengingat angka partisipasi masyarakat terhadap penyelenggaran pemilihan umum kepala daerah semakin hari, semakin menurut.

\section{B. Pembahasan}

Dari pemasalahan tersebut maka dalam tulisan ini akan menguraikan dua hal utama yaitu pertama dsar pelaksanaan partisipasi masyarakat dalam pemilihan umum kepala daerah, dan asas keterbukaan sebagai prinsip partisipasi masyarakat dalam pemilihan umum kepala daerah.

\section{Pelaksaan Partisipasi Masyarakat Dalam Pemilihan Umum Kepala Daerah.}

Jika dilusuri, maka banyak yang dapat dijadikan sebagai dasar dalam penyelenggaran partisipasi masyakat dalam pemilihan umum kepala berdsarkan pada aturan hukum nasional. Diantara aturan tersebut adalah sebagai berikut:

1. Undang-Undang Nomor 7 Tahun 2017 Tentang Pemilihan Umum; 
2. Undang-Undang Nomor 10 Tahun 2016 Tentang Perubahan Kedua atas UndangUndang Nomor 1 Tahun 2015 Tentang Penetapan Peraturan Pemerintah Pengganti Undang-Undang Nomor 1 Tahun 2014 Tentang Pemilihan Gubernur, Bupati dan Walikota menjadi Undang-Undang

3. Undang-undang Nomor 15 Tahun 2011 tentang Penyelenggara Pemilu;

4. Peraturan Bawaslu Nomor 13 Tahun 2012 tentang Tata Cara Pengawasan Pemilu yang didalamnya mengatur tentang bentuk-bentuk partisipasi masyarakat.

Keseluruhan aturan terkait partisipasi masyarakat dalam pemilihan umum kepala daerah sebagaimana etrsebut diatas tersebut sebenanya dimaksudkan sebagai salah satu bentuk jamina keharusan warga masyarakat berpastisipasi dalam pemilihan umum. Adanya jaminan partisipasi masyarakat dalam rangka membangun jejaring pengawasan pemilu yang melibatkan masyarakat secara partisipatif. Pengawasan partisipatif pemilu sebagai hasil kesadaran akan memiliki kepemiluan (sense of belonging) supaya lebih baik. Formulasi pengawasan partisipatif dapat dibentuk penyadaran dan kesepemahaman tentang pola dan pandangan tentang pengawasan partisipatif.

\section{Asas Keterbukaan Sebagai Prinsip Partisipasi Masyarakat Dalam Pemilihan} Umum Kepala Daerah.

Sesuai dengan prinsip negara hukum, maka setiap kebijakan penyelenggara negara termasuk pemerintahan daerah, senantiasa kebijakan yang bersangkutan agar dapat diimplementasikan haruslah dikemas dalam bentuk produk hukum. Kebijakan daerah haruslah dikemas dalam bentuk pranata hukum daerah, baik dalam bentuk keputusan kepala daerah, keputusan lembaga, maupun dalam bentuk peraturan daerah. Oleh karena itu setiap pembentukan dan evaluasi atas sesuatu, harus bersendikan asas demokrasi.

Kepustakaan hukum yang membahas tentang demokrasi memaparkan keterbukaan sebagai salah satu syarat minimum demokrasi yang merupakan suatu conditio sine qua non. Dengan demikian, secara nalar, bahwa partisipasi masyarakat dalam berbagai bentuk untuk mensukseskan pemilihan umum kepala daerah merupakan salah satu bentuk dari pelaksanaan asas keterbukaan dalam penyelengaraan pemerintah.

Dalam UUD 1945 tidak kita temukan rumusan secara eksplisit tentang asas keterbukaan. Namun demikian isu keterbukaan dalam pelaksanaan pemerintahan telah merebak di tanah air sejak tahun delapan puluhan dan sebagai realisasinya dalam bidang politik dan sosial, Pada tahun 1986 Wakil Presiden membuka kotak pos 5000. 
Melalui kotak pos itu, rata-rata tiap hari masuk surat-surat dari seluruh penjuru tanah air sekitar 50 surat. Pun bergitu juga yang dilakukan oleh pemerintahan SBY (Susilo Bambang Yudoyono) dan pemerintahan Jokowi dengan memanfaatkan media sosial sebagai basis menjaring informasi delam rangkan memaksimalkan partisipasi publik dalam penyelenggaraan pemerintahan.

Keterbukaan, baik "openheid" maupun "apenbaar-heid" ("openheid" adalah suatu sikap mental berupa kesediaan untuk memberi informasi dan kesediaan untuk menerima pendapat pihak lain; "openbaar-heid" menunjukkan suatu keadaan) sangat penting artinya bagi pelaksanaan pembentukan peraturan perundang-undangan yang baik dan demokratis. Dengan demikian keterbukaan dipandang sebagai suatu asas administrasi dan ketatanegaraan mengenai pelaksanaan wewenang secara layak (staatsrehtelijk beginsel van behoorlijke bevoegdheidsuitoefening). ${ }^{1}$ Begitu pentingnya arti keterbukaan sehingga seorang sarjana Belanda - Thoerbecke mengatakan : "Openbaarheid is licht, geheimbouding is duisternis".

Dalam hukum tata negara dan hukum administrasi, "keterbukaan" merupakan asas penyelenggaraan pemerintahan yang bertumpu atas asas demokrasi (partisipasi). Demokrasi perwakilan sudah lama dirasakan tidak memadai. Pernyataan seperti yang pernah diucapkan Prof. Mr. R. Boedisoesetyo pada pidato inagurasinya sebagai Guru Besar Luar Biasa Hukum Tata Negara dan Hukum Tata Pemerintahan pada Fakultas Hukum Universitas Airlangga yang diucapkan pada hari Rabu, tanggal 10 Nopember 1958 kiranya sudah ketinggalan dalam kehidupan demokrasi modern. Dalam pidato tersebut dikatakan : Sekali anggota-angguta itu terpilih dan terbentuk DPR, maka rakjat yang berdaulat itu tidak mempunjai wewenang lagi untuk menjatakan kemaunnja .......

Kalau pikiran itu kita ikuti maka setelah rakyat memberikan suaranya pada hari pemungutan suara, maka selanjutnya rakyat itu tidak tahu apa-apa lagi tentang pelaksanaan pemerintahan. Mudah-mudahan bukan pikiran itulah yang mewarnai pikiran tentang pemilihan umum sebagai pesta demokrasi, karena dengan pikiran seperti itu setelah pesta itu berakhir, maka hanya tinggal suatu kenangan berupa kesan tentang pesta itu sendiri. Bagi suatu negara demokrasi pelaksanaan pemilihan umum

\footnotetext{
${ }^{1}$ P. De Haan, 1986, Bestuursrecht in Sociale Rechtsstaat, deel 2 Bestuurshandelingen en waarborgen, Kluwer Deventer,: 122, Philipus M. Hadjon, 1999, Keterbukaan Pemerintahan dan Tanggung Gugat Pemerintahan, makalah disampaikan pada seminar Hukum Nasional ke-VI dengan tema Reformasi Hukum Menuju Masyarakat Madani, Badan Pembinaan Hukum Nasional Departemen Kehakiman Republik Indonesia, Jakarta, 12 - 15 Oktober, : 4
} 
bukan satu-satunya instrumen demokrasi. Konsep demokrasi dan instrumennya telah jauh berkembang.

Sekitar tahun enampuluhan-tujuhpuluhan muncul suatu konsep demokrasi yang disebut demokrasi partisipasi (seperti Carol Pateman dalam bukunya, Participation and democratic theory, 1970). Dalam konsep demokrasi partisipasi rakyat mempunyai hak untuk ikut memutuskan (medebeslissingsrecht) dalam proses pengambilan keputusan pemerintahan (besluitvormingsproces) 'Dalam praktek pemerintahan di Belanda sebagai pelaksanaan asas ketebukaan mula-mula melalui asas "fair play" sebagai salah satu dari apa yang disebut "algemene beginselen van behoorlijk bestuur" yang dalam praktek Peradilan Tata Usaha Negara di Indonesia dewasa ini dikenal dengan nama "Asas-Asas Umum Pemerintahan yang Baik" (AAUPB). Dengan lahirnya wet openbaarheid van bestuur (WOB) yang efektif sejak tanggal 1 Mei 1980 asas "fair play" dimasukkan dalam wet tersebut. Dalam WOB dibedakan dua macam keterbukaan pemerintahan, yaitu keterbukaan aktif dilaksanakan atas prakarsa pemerintah sedangkan keterbukaan pasif atas permintaan warga masyarakat. ${ }^{2}$

Keterbukaan informasi yang dibedakan atas keterbukaan aktif dan pasif, berkaitan dengan dokumen-dokumen pemerintahan. Keterbukaan informasi dimungkinkan dalam batas-batas tertentu bagi masyarakat untuk mengetahui dokumen-dokumen pemerintah. Fiksi hukum yang menyatakan bahwa "setiap orang dianggap mengetahui undangundang" tidaklah ada artinya, apabila undang-undang tidak dipublikasikan secara luas. ${ }^{3}$

Keterbukaan prosedur berkaitan dengan "besluitvormingsprocedures" dan salah satu dari "besluit" yang sangat penting adalah "beschikking” yang dalam UU No. 30 Tahun 2014 disebut keputusan administrasi tata usaha negara. Keterbukaan dalam prosedur memungkinkan masyarakat : meeweten (ikut mengetahui); meedenken (ikut memikirkan); meespreken (bermusyawarah); dan meebeslissen (ikut memutuskan dalam rangka pelaksanaan); medebeslissingsrecht (hak ikut memutus). ${ }^{4}$

Asas-asas tersebut harus dituangkan dalam prosedur pengambilan keputusan pemerintahan, baik menyangkut suatu rencana, kebijakan, pembentukan peraturan perundang-undangan maupun suatu keputusan tata usaha negara. Keterbukaan merupakan pelaksanaan asas demokrasi, bahkan merupakan conditio sine qua non asas demokrasi. Keterbukaan memungkinkan partisipasi masyarakat secara aktif dalam

\footnotetext{
${ }^{2}$ Van Wijk-Konijnenbelt, 1984, Hoofdstukken van administratief recht, vijfde druk, Vuga, S-Gravenhage, : 42

${ }^{3}$ Duk-Loeb-nicolai, 1981, Bestuursrecht, Bowar-boek, : 157,

${ }^{4}$ P. De Haan, op cit., : 138
} 
pembentukan peraturan perundang-undangan. Dalam rangka pembentukan peraturan perundangan-undangan yang demokratis, asas keterbukaan perlu mendapat perhatian karena demokrasi perwakilan saja dewasa ini sudah tidak memadai. Termasuk didalamnya terkait dengan pengaturan keterlibatan atau partisipasi masyarakat dalam penyelenggaraan pemilihan umum kepala daerah di daerah.

Keterbukaan dalam hubungan antara pemerintah dan rakyat, kiranya merupakan prioritas pemikiran untuk mendapat perhatian khusus, agar dapat segera diwujudkan dalam proses hubungan antara pemerintah dan rakyat. Untuk itu suatu kodifkasi hukum administrasi umum, khususnya mengenai prosedur pemerintahan seyogyanya perlu mendapat perhatian, yang membuka peluang kodifikasi administrasi secara bertahap. Kodifikasi yang demikian tidak hanya punya arti bagi pelaksanaan asas negara hukum, tetapi juga untuk mewujudkan asas kekuasaan berdasarkan atas hukum secara nyata. Dalam mengantisipasi era globalisasi usaha tersebut perlu mendapat prioritas, karena hukumlah yang mempunyai peran utama dalam lalu lintas ekonomi global. Pembangunan yang hanya menempatkan posisi hukum sebagai sarana, diragukan kemampuannya untuk mewujudkan negara Hukum Republik Indonesia, yang intinya adalah mewujudkan cita hukum (rechts idee). ${ }^{5}$

Pada dasarnya, prinsip keterbukaan informasi yang khususnya dalam penyelenggaraan pemerintahan telah diatur dalam Undang-Undang tentang Pemerintahan Daerah. dan juga berpedoman pada asas-asas umum penyelenggaraan negara sebagaimana diatur dalam UU No. 30 Tahun 2014 tentang Admnistrasi Pemerintahan; Penyelenggaraan pemerintahan berpedoman pada asas-asas umum penyelenggaraan negara yang terdiri atas: Pertama , Asas Kepastian Hukum, yaitu asas dalam suatu negara hukum yang mengutamakan landasan peraturan perundangundangan yang berlaku, kepatutan, dan keadilan dalam setiap kebijakan. Kedua, Asas Tertib Penyelenggara Negara, yaitu asas yang menjadi landasan keteraturan, keserasian, dan keseimbangan dalam pengendalian penyelenggaraan negara. Ketiga, Asas Kepentingan Umum. Keempat, Asas Keterbukaan, asas yang membuka diri terhadap hak-hak masyarakat untuk memperoleh informasi yang benar, jujur, dan tidak diskriminatif tentang penyelenggaraan negara dengan tetap memperhatikan perlindungan atas hak-hak asas pribadi, golongan, dan rahasia negara. Kelima, Asas Proporsionalitas, asas yang mengutamakan keseimbangan antara hak dan kewajiban

${ }^{5}$ P. de Haan, op cit., : 137, Philipus M. Hadjon, 1999, ibid., : 9 
penyelenggara negara. Keenam, Asas Profesionalitas, asas yang mengutamakan keahlian yang berlandaskan kode etik dan ketentuan peraturan perundang-undangan yang berlaku. Ketujuh, Asas Akuntabilitas, asas yang menentukan bahwa setiap kegiatan dan hasil akhir dari kegiatan penyelenggara negara harus dapat dipertanggungjawabkan kepada masyarakat atau rakyat, sebagai pemegang kedaulatan tertinggi negara sesuai dengan ketentuan peraturan perundang-undangan yang berlaku. Kedelapan, Asas Efisiensi dan Asas Efektivitas.

\section{Simpulan}

Berdasarkan uraian tersebut maka dapat disimpulkan bahwa prinsip dasar partisipasi masyarakat terhadap penyelenggaran pemilihan umum kepala daerah harus senantiasa berdasarkan pada asas keterbukaan sebagai prinsip pokok partisipasi masyarakat. Selain itu juga harus berdasarkan pada Pertama, Asas Kepastian Hukum, yaitu asas dalam suatu negara hukum yang mengutamakan landasan peraturan perundang-undangan yang berlaku, kepatutan, dan keadilan dalam setiap kebijakan. Kedua , Asas Tertib Penyelenggara Negara, yaitu asas yang menjadi landasan keteraturan, keserasian, dan keseimbangan dalam pengendalian penyelenggaraan negara. Ketiga, Asas Kepentingan Umum. Keempat, Asas Keterbukaan, asas yang membuka diri terhadap hak-hak masyarakat untuk memperoleh informasi yang benar, jujur, dan tidak diskriminatif tentang penyelenggaraan negara dengan tetap memperhatikan perlindungan atas hak-hak asas pribadi, golongan, dan rahasia negara. Kelima, Asas Proporsionalitas, asas yang mengutamakan keseimbangan antara hak dan kewajiban penyelenggara negara. Keenam, Asas Profesionalitas, asas yang mengutamakan keahlian yang berlandaskan kode etik dan ketentuan peraturan perundang-undangan yang berlaku. Ketujuh, Asas Akuntabilitas, asas yang menentukan bahwa setiap kegiatan dan hasil akhir dari kegiatan penyelenggara negara harus dapat dipertanggungjawabkan kepada masyarakat atau rakyat, sebagai pemegang kedaulatan tertinggi negara sesuai dengan ketentuan peraturan perundang-undangan yang berlaku. Kedelapan, Asas Efisiensi dan Asas Efektivitas. 


\section{Daftar Pustaka}

Hadjon, Philipus M., 1999, Keterbukaan Pemerintahan dan Tanggung Gugat Pemerintahan, makalah disampaikan pada seminar Hukum Nasional ke-VI dengan tema Reformasi Hukum Menuju Masyarakat Madani, Badan Pembinaan Hukum Nasional Departemen Kehakiman Republik Indonesia, Jakarta, 12 - 15 Oktober 1999

P. De Haan, 1986, Bestuursrecht in Sociale Rechtsstaat, deel 2 Bestuurshandelingen en waarborgen, Kluwer Deventer.

Peraturan Bawaslu Nomor 13 Tahun 2012 tentang Tata Cara Pengawasan Pemilu yang didalamnya mengatur tentang bentuk-bentuk partisipasi masyarakat.

Undang-Undang Nomor 10 Tahun 2016 Tentang Perubahan Kedua atas UndangUndang Nomor 1 Tahun 2015 Tentang Penetapan Peraturan Pemerintah Pengganti UndangUndang Nomor 1 Tahun 2014 Tentang Pemilihan Gubernur, Bupati dan Walikota menjadi Undang-Undang

Undang-undang Nomor 15 Tahun 2011 tentang Penyelenggara Pemilu;

Undang-Undang Nomor 7 Tahun 2017 Tentang Pemilihan Umum;

UU No. 30 Tahun 2014 tentang Admnistrasi Pemerintahan

Van Wijk-Konijnenbelt, 1984, Hoofdstukken van administratief recht, vijfde druk, Vuga, S-Gravenhage. 